\title{
ANTIVENOM ACTION ON RENAL EFFECTS INDUCED BY Thalassophryne nattereri VENOM
}

\author{
Martins AMC (1), Barbosa PSF (2), Sousa DF (1), Alves CD (1), Menezes DB (3), \\ Lima C (4), Lopes-Ferreira M (4), Fonteles MC (5), Monteiro HSA (2)
}

(1) Department of Clinical and Toxicological Analyses, Federal University of Ceará, Fortaleza, Ceará State, Brazil; (2) Department of Physiology and Pharmacology, Federal University of Ceará, Fortaleza, Ceará State, Brazil; (3) Department of Pathology and Legal Medicine, Federal University of Ceará, Fortaleza, Ceará State, Brazil; (4) Special Laboratory of Applied Toxinology, Butantan Institute, São Paulo, São Paulo State, Brazil; (5) Mackenzie Presbyterian University, São Paulo, São Paulo State, Brazil.

ABSTRACT: Thalassophryne nattereri (niquim) is a venomous fish responsible for numerous accidents involving fishermen in northern and northeastern Brazil. The aim of the present investigation was to evaluate the action of antivenom on renal effects caused by Thalassophryne nattereri venom. Isolated kidneys of Wistar rats were perfused with a previously dialyzed Krebs-Henseleit solution containing $6 \mathrm{~g} \%$ bovine serum albumin. The antivenom action was studied through perfusion pressure (PP), renal vascular resistance (RVR), urinary flow (UF) and glomerular filtration rate (GFR). The niquim venom (1 $\mu \mathrm{g} / \mathrm{mL})$, the antivenom alone $(1 \mu \mathrm{g} / \mathrm{mL})$ or the venom incubated with antivenom were added to the system 30 minutes after the beginning of each perfusion. Previous works have shown venom induced-alterations of renal function parameters. In the isolated rat kidney, $T$. nattereri venom $(1 \mu \mathrm{g} / \mathrm{mL})$ increased the perfusion pressure and renal vascular resistance at 60,90 and 120 minutes. UF and GFR also increased at 60, 90 and 120 minutes when compared with the control group; however, no effects were observed on the percent of sodium $\left(\% \mathrm{TNa}^{+}{ }_{\text {control }}=81.1 \pm 0.86 ; \% \mathrm{TNa}_{60}=78.04 \pm 1.18 ; \% \mathrm{TNa}_{90}=\right.$ $\left.76.16 \pm 3.34 ; \% \mathrm{TNa}_{120}=79.49 \pm 0.87\right)$ and potassium $\left(\% \mathrm{TK}_{\text {control }}^{+}=72.29 \pm 1.12 ; \% \mathrm{TK}_{60}^{+}\right.$ $\left.=75.41 \pm 0.65 ; \% \mathrm{TK}^{+}{ }_{90}=71.23 \pm 2.55 ; \% \mathrm{TK}^{+}{ }_{120}=76.62 \pm 1.04\right)$ tubular transport. The administration of the antivenom $(1 \mu \mathrm{g} / \mathrm{mL})$ incubated with venom $(1 \mu \mathrm{g} / \mathrm{mL})$ reduced the changes in PP, RVR, UF and GFR provoked by Thalassophryne nattereri venom. The group perfused with venom alone showed a moderate deposit of a proteinaceous material in the tubules and urinary space. The group perfused with the antivenom presented similar results to the control group. In conclusion, the antivenom was able to decrease the effects induced by $T$. nattereri venom in isolated rat kidney.

KEY WORDS: Thalassophryne nattereri, antivenom, kidney.

CONFLICTS OF INTEREST: There is no conflict.

\section{CORRESPONDENCE TO:}

HELENA SERRA AZUL MONTEIRO, Departamento de Fisiologia e Farmacologia, Faculdade de Medicina, Universidade Federal do Ceará, Rua Cel. Nunes de Melo, 1127, Fortaleza, CE, 60.430-370, Brasil. Phone: +55 853366 8437. Fax: +55 85 3366 5212. Email: martinsalice@gmail.com; serrazul@baydenet.com.br. 


\section{INTRODUCTION}

Thalassophryne nattereri, also known as niquim, is a venomous fish responsible for several accidents among fishermen in northern and northeastern Brazil (1-3). On coast of Ceará State, from 1992 to 2002, 16 envenomation cases by T. nattereri were registered (4). The number of injuries is not so small considering an active study on envenomation frequency that shows a very high incidence in all fisherman communities from northeast region of Brazil. The Thalassophryne bite causes pain, edema, erythema and occasional necrosis, which are also seen in highly necrotic venoms, as the one from freshwater stingrays (2).

T. nattereri venom is composed of proteolytic and myotoxic toxins devoid of phospholipase $A_{2}$ activity (5). Analysis of skeletal muscles of mice injected with the venom revealed damage to muscles (6). Some studies demonstrated that the action of the venom on endothelium may contribute to ischemia (7). On isolated rat kidney we observed that $T$. nattereri venom causes changes in renal function including increase in: perfusion pressure, renal vascular resistance, urinary flow and glomerular filtration rate (8). Local acute inflammatory response induced by the venom was also registered (9). Cytokines, as TNF- $\alpha$, IL-1 $\beta$ and IL-6, and a weak leukocyte influx were detected on footpads of mice. Additionally, a cytotoxic effect of the venom on mononuclear cells was recorded. T. nattereri venom content stimulates an association of cytokines of both Th1 and Th2 profile, with a notable IL-5 production and secretion of specific $\lg G 1$ and total $\lg E$ isotypes, which may also affect $B$ cells and induce a memory antibody response by the secretion of protective $\lg$ subclasses (10).

Anti-inflammatory drugs, like dexamethasone and indomethacin, are inefficient to control envenomation symptoms (11). It was demonstrated that harmful effects of $T$. nattereri envenomation on mice could be prevented by previous long-lasting immunization (12). Since systemic antibody levels could be induced by this venom and protect mice against venom deleterious properties, we therefore tested the capacity of antibodies present in horse serum to neutralizing or reducing renal effects induced by the fish venom. 


\section{MATERIALS AND METHODS}

\section{Venom}

Specimens of adult $T$. nattereri fish were collected in the Brazilian state of Alagoas. The venom was obtained according to the technique described by Lopes-Ferreira et al. (5). Protein concentrations were determined through a colorimetric method (13). Standard curves were constructed using bovine serum albumin (Sigma Chemicals, USA) diluted in duplicate.

\section{Serum Antivenom of $T$. nattereri}

Hyperimmune serum was obtained from horses injected with T. nattereri venom (12). Each animal received $26 \mathrm{mg}$ of venom during the process.

\section{Kidney Perfusion}

Adult male Wistar rats (260 to $320 \mathrm{~g}$ ) were fasted for 24 hours with free access to water. The animals were anesthetized with sodium pentobarbitone $(50 \mathrm{mg} / \mathrm{kg}, \mathrm{IP})$. After careful dissection of the right kidney, the right renal artery was cannulated via the mesenteric artery without interruption of blood flow $(14,15)$. The perfusate consisted of a modified Krebs-Henseleit solution (MKHS) containing $118.0 \mathrm{NaCl} ; 1.2$ $\mathrm{KCl} ; 1.18 \mathrm{KH}_{2} \mathrm{PO}_{4} ; 1.18 \mathrm{MgSO}_{4} .7 \mathrm{H}_{2} \mathrm{O} ; 2.50 \mathrm{CaCl}_{2}$ and $25.0 \mathrm{NaHCO}_{3}$ in mmoles/L. Six grams of bovine serum albumin (BSA) were added to $100 \mathrm{~mL}$ of MKHS, and dialyzed for 48 hours at $4^{\circ} \mathrm{C}$ against ten volumes of MKHS. Immediately before the beginning of each perfusion protocol, $100 \mathrm{mg}$ of urea, $50 \mathrm{mg}$ of inulin and $50 \mathrm{mg}$ of glucose were added to every $100 \mathrm{~mL}$ of perfusate and $\mathrm{pH}$ was adjusted to 7.4. Each experiment lasted 120 minutes and the recirculating perfusion system employed 100 $\mathrm{mL}$ of MKHS.

Perfusion pressure (PP) was measured at the tip of the stainless steel cannula in the renal artery. Samples of urine and perfusate were collected at 10-minute intervals for analysis of sodium and potassium level by flame photometry; inulin was determined by direct hydrolysis and osmolality was measured in a vapor pressure osmometer (Wescor 5100C, USA) (16). The Thalassophryne nattereri venom and antivenom were preincubated at $37^{\circ} \mathrm{C}$ for 30 minutes before addition in perfusion system. The venom $(1 \mu \mathrm{g} / \mathrm{mL})$, the antivenom alone $(1 \mu \mathrm{g} / \mathrm{mL})$ or venom incubated with antivenom were added to the system 30 minutes after the beginning of each perfusion. Renal vascular resistance (RVR), urinary flow (UF) and glomerular filtration rate (GFR) were 
determined (17). Results were compared to a control group where the kidneys were perfused with Krebs-Henseleit solution alone. Statistical analysis was performed by means of one-way ANOVA and Bonferroni t-test with the level of significance set at $p$ $<0.05$ and $\mathrm{n}=6$ to each group.

\section{Renal Histological Evaluation}

After the renal perfusion experiment, both right and left kidneys were removed and fixed in $10 \%$ formaldehyde for histological processing. Kidney tissue was embedded in paraffin, cut into 3- to 5- $\mu \mathrm{m}$ sections, stained with hematoxylin-eosin and further processed for light microscopy (Olympus BX41, USA). The photomicrographs were taken by means of a digital camera (Nikon Coolpix 885, Japan).

\section{Ethical Committee}

The experimental protocol was approved by the Federal University of Ceará Ethics Committee on Animal Research.

\section{RESULTS}

\section{Renal Perfusion}

\section{Control group perfused with modified Krebs-Henseleit solution}

The renal parameters of the control group remained stable throughout the experimental perfusion period.

\section{Renal effects induced by Thalassophryne nattereri venom}

Previous results showed that Thalassophryne nattereri venom can cause alterations of renal function parameters after the 30 minutes of internal control. On the isolated rat kidney $T$. nattereri venom $(1 \mu \mathrm{g} / \mathrm{mL})$ increased the perfusion pressure (Figure 1 A) and renal vascular resistance (Figure $1-B$ ) at 60, 90 and 120 minutes. UF (Figure $2-\mathrm{A}$ ) and GFR (Figure $2-\mathrm{B}$ ) were also augmented at 60, 90 and 120 minutes when compared with the control group. However, the venom had no effect on the percent of sodium $\left(\% \mathrm{TNa}^{+}{ }_{\text {control }}=81.1 \pm 0.86 ; \% \mathrm{TNa}_{60}=78.04 \pm 1.18\right.$; $\left.\%_{\mathrm{TNa}+}{ }_{90}=76.16 \pm 3.34 ; \% \mathrm{TNa}{ }_{120}=79.49 \pm 0.87\right)$ and potassium $\left(\% \mathrm{TK}_{\text {control }}^{+}=\right.$ $72.29 \pm 1.12 ; \% \mathrm{TK}_{60}^{+}=75.41 \pm 0.65 ; \% \mathrm{TK}^{+}{ }_{90}=71.23 \pm 2.55 ; \% \mathrm{TK}^{+}{ }_{120}=76.62 \pm 1.04$ ) tubular transport. 

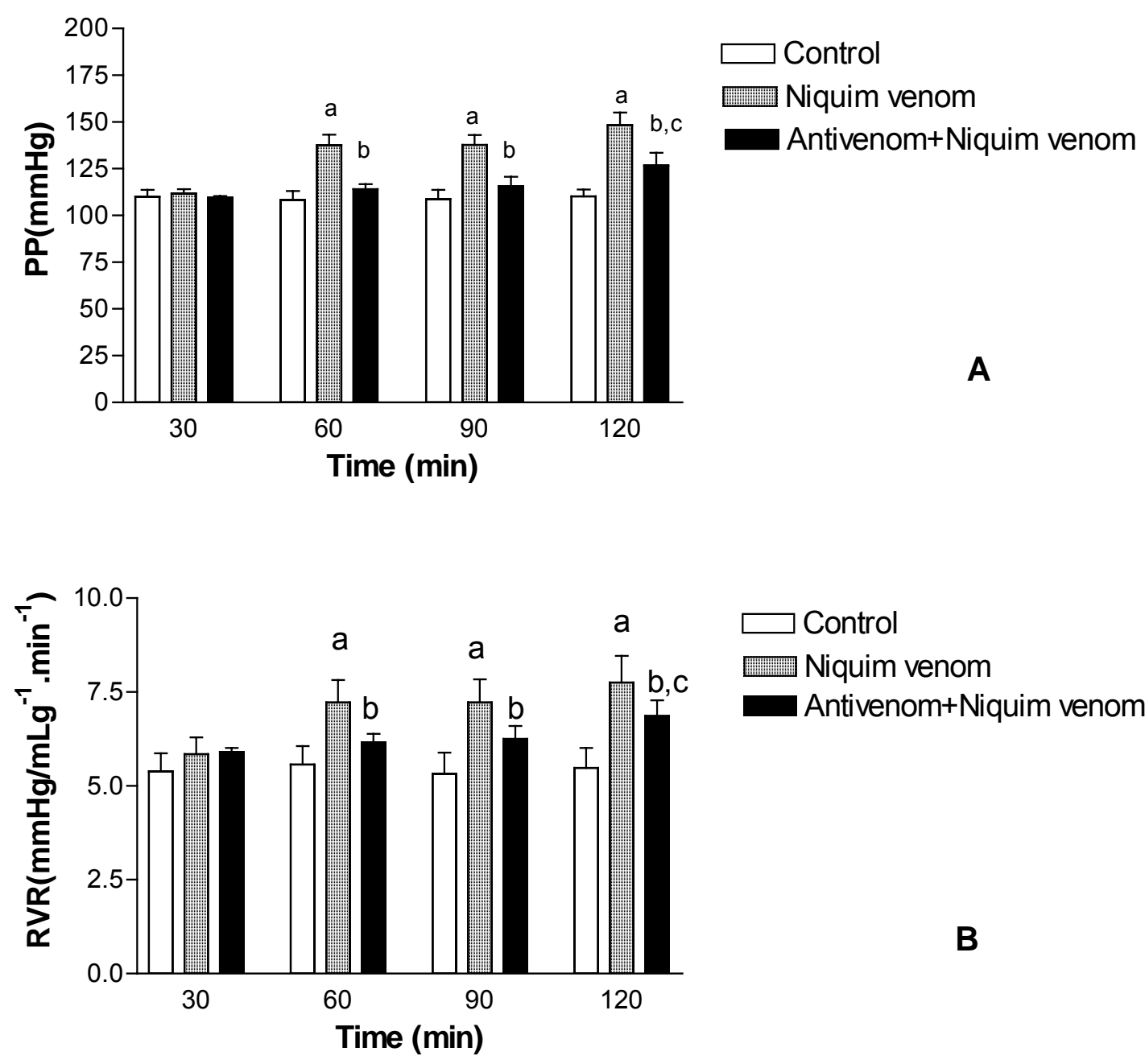

$\square$ Control

Niquim venom

Antivenom+Niquim venom

Figure 1. Action of the antivenom $(1 \mu \mathrm{g} / \mathrm{mL})$ on effects of Thalassophryne nattereri venom $(1 \mu \mathrm{g} / \mathrm{mL})$ on perfusion pressure (PP; A) and renal vascular resistance (RVR; B). Data are expressed as means \pm SEM from six different animals. ANOVA was employed for statistical analysis by comparison with the control group in which kidneys were perfused with only MKHS with ${ }^{\mathrm{a}, \mathrm{b}, \mathrm{c}} \mathrm{p}<0.05$.

a: comparison between control group and niquim venom group; ${ }^{\text {b. }}$ comparison between niquim venom group and antivenom plus niquim venom group; ${ }^{c}$ : comparison between control group and antivenom plus niquim venom group. 

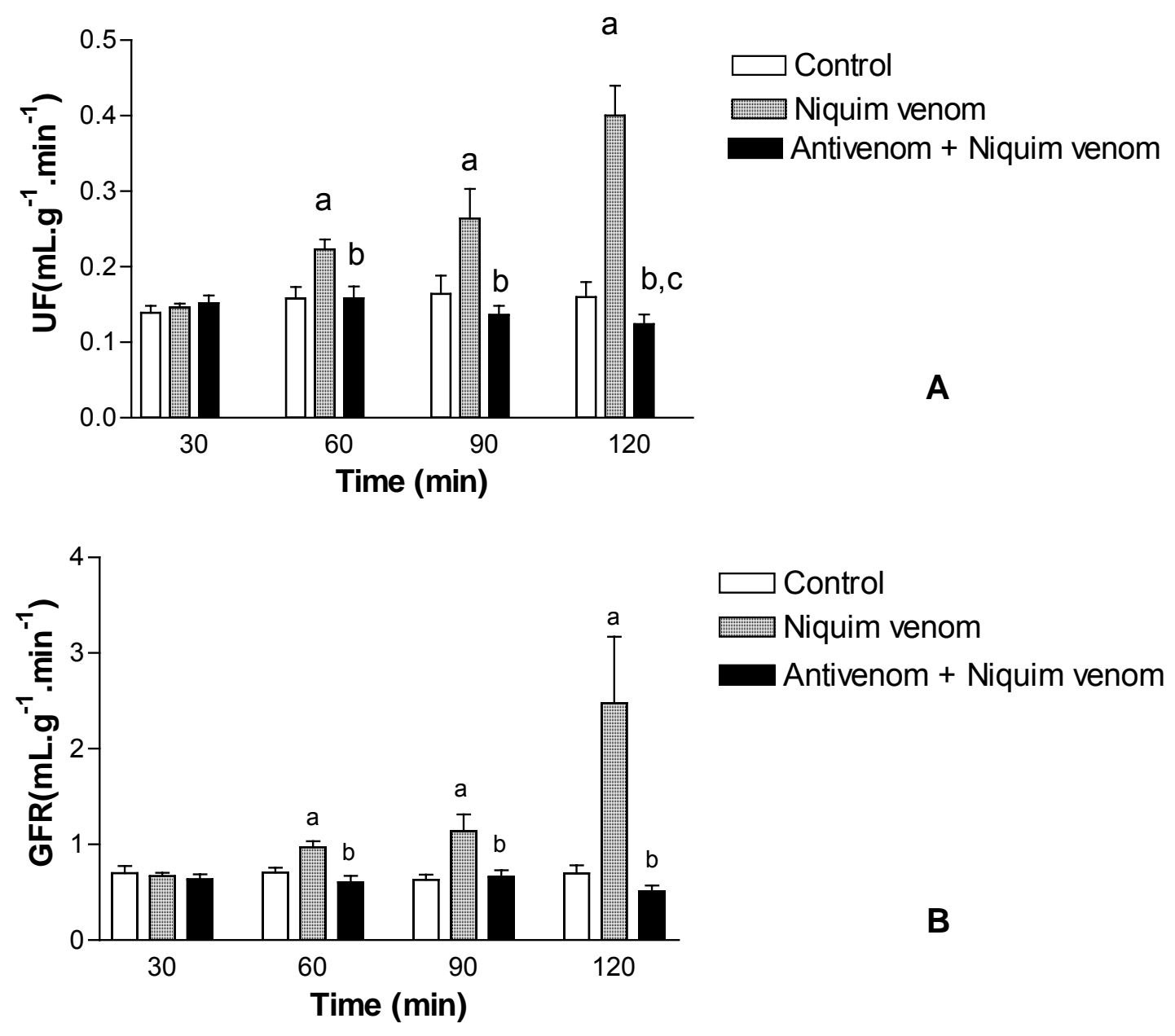

Figure 2. Action of the antivenom $(1 \mu \mathrm{g} / \mathrm{mL})$ on niquim venom effects $(1 \mu \mathrm{g} / \mathrm{mL})$ on urinary flow (UF; A) and glomerular filtration rate (GFR; B). Data are expressed as means \pm SEM from six different animals. ANOVA was employed for statistical analysis by comparison with the control group in which kidneys were perfused with only MKHS with ${ }^{a, b, c} p<0.05$.

${ }^{\mathrm{a}}$ : comparison between control group and niquim venom group; ${ }^{\mathrm{b}}:$ comparison between niquim venom group and antivenom plus niquim venom group; ${ }^{c}$ : comparison between control group and antivenom plus niquim venom group. 

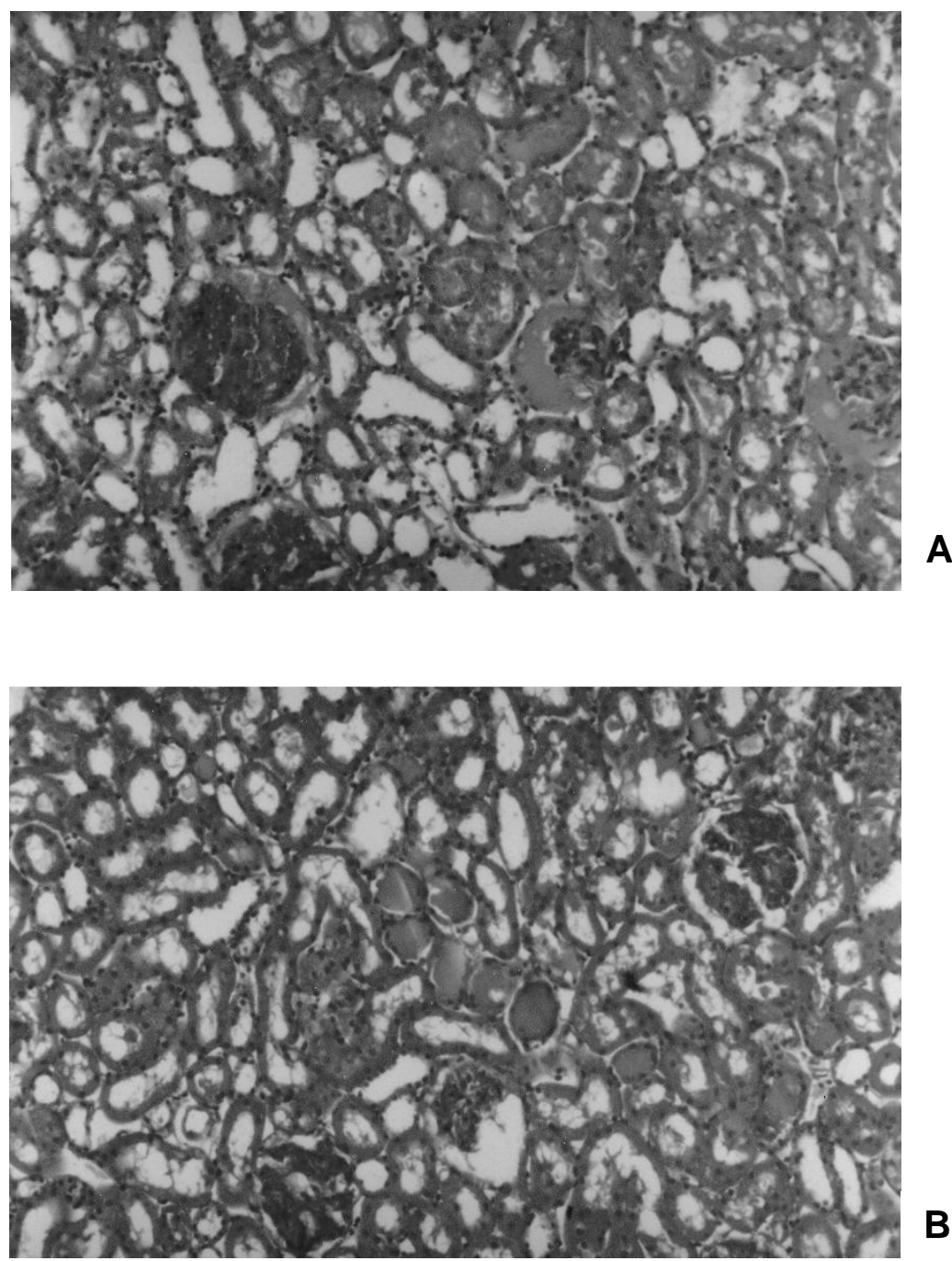

Figure 3. Action of the antivenom $(1 \mu \mathrm{g} / \mathrm{mL})$ on effects of Thalassophryne nattereri venom $(1 \mu \mathrm{g} / \mathrm{mL})$. The group that received venom only showed a moderate deposit of proteinaceous material in the tubules and urinary space $(\mathbf{A})$. The kidneys perfused with venom plus antivenom presented a mild deposit of proteinaceous material in glomeruli and tubules (B). Hematoxylin-eosin stain (20x). Canon PowerShot A 95, $5.0 \mathrm{mp}$.

\section{Effects of Thalassophryne nattereri antivenom on isolated kidney}

The administration of antivenom $(1 \mu \mathrm{g} / \mathrm{mL})$ caused a slight increase in: $\mathrm{PP}\left(\mathrm{PP}_{\text {control }}=\right.$ $110.40 \pm 1.10 \mathrm{mmHg} ; \mathrm{PP}_{60}=115.1 \pm 1.60 \mathrm{mmHg} ; \mathrm{PP}_{90}=113.70 \pm 4.10 \mathrm{mmHg} ; \mathrm{PP}_{120}$ $=129.00 \pm 8.80 \mathrm{mmHg}) ; \operatorname{RVR}\left(\mathrm{RVR}_{\text {control }}=5.36 \pm 0.14 \mathrm{mmHg} / \mathrm{mL}^{-g^{-1}} \cdot \mathrm{min}^{-1} ; \mathrm{RVR}_{60}=\right.$

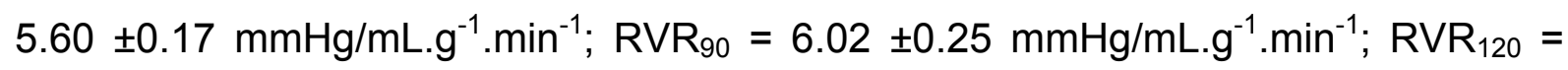
$\left.6.26 \pm 0.46 \mathrm{mmHg} / \mathrm{mL} \cdot \mathrm{g}^{-1} \cdot \mathrm{min}^{-1}\right)$; in UF $\left(\mathrm{UF}_{\text {control }}=0.135 \pm 0.019 \mathrm{~mL} \cdot \mathrm{g}^{-1} \cdot \mathrm{min}^{-1} ; \mathrm{UF}_{60}=\right.$ 
$0.140 \pm 0.016 \mathrm{~mL} \cdot \mathrm{g}^{-1} \cdot \mathrm{min}^{-1} ; \mathrm{UF}_{90}=0.159 \pm 0.026 \mathrm{~mL} \cdot \mathrm{g}^{-1} \cdot \mathrm{min}^{-1} ; \mathrm{UF}_{120}=0.170 \pm 0.047$ $\left.\mathrm{mL} \cdot \mathrm{g}^{-1} \cdot \mathrm{min}^{-1}\right)$; in GFR (GFR control $=0.778 \pm 0.114 \mathrm{~mL} \cdot \mathrm{g}^{-1} \cdot \mathrm{min}^{-1} ; \mathrm{GFR}_{60}=0.763 \pm 0.083$ $\mathrm{mL} \cdot \mathrm{g}^{-1} \cdot \mathrm{min}^{-1} ; \mathrm{GFR}_{90}=0.850 \pm 0.382 \mathrm{~mL} \cdot \mathrm{g}^{-1} \cdot \mathrm{min}^{-1} ; \mathrm{GFR}_{120}=0.709 \pm 0.254 \mathrm{~mL} \cdot \mathrm{g}^{-1} \cdot \mathrm{min}^{-}$ $\left.{ }^{1}\right)$; in $\% \mathrm{TNa}^{+}\left(\% \mathrm{TNa}^{+}{ }_{\text {control }}=81.1 \pm 0.86 ; \% \mathrm{TNa}+{ }_{60}=78.04 \pm 1.18 ; \% \mathrm{TNa}+{ }_{90}=76.16\right.$ $\left.\pm 3.34 ; \% \mathrm{TNa}+{ }_{120}=79.49 \pm 0.87\right)$ and in $\% \mathrm{TK}^{+}\left(\%_{\mathrm{TK}^{+}}\right.$control $=72.29 \pm 1.12 ; \% \mathrm{TK}_{60}^{+}=$ $\left.75.41 \pm 0.65 ; \% \mathrm{TK}_{90}^{+}=71.23 \pm 2.55 ; \% \mathrm{TK}^{+}{ }_{120}=76.62 \pm 1.04\right)$ tubular transport. The effects of Thalassophryne nattereri antivenom on isolated kidney were not significant when compared with the control group.

\section{Antivenom action on renal effects provoked by Thalassophryne nattereri venom}

The antivenom was able reverted the renal effects induced by Thalassophryne nattereri venom (Figures 1 and 2). Antivenom $(1 \mu \mathrm{g} / \mathrm{mL}$ ) incubated with venom $(1 \mu \mathrm{g} / \mathrm{mL})$ inhibited in about $15 \%$ the increase of PP and RVR. UF was reduced in $29 \%, 48 \%$ and $69 \%$ respectively at 60,90 and 120 minutes and GFR was diminished in $38 \%, 42 \%$ and $79 \%$ at 60,90 and 120 minutes, respectively.

\section{Results of Histological Alterations in Kidney}

Analysis of the control group showed small amount of a proteinaceous material in the renal tubules, although no alteration in the urinary space was detected. The group perfused only with the venom showed a moderate deposit of a proteinaceous material in the tubules and urinary space (8). The group perfused only with the antivenom presented small amount of a proteinaceous material in the renal tubules, similar to the control group. The kidneys perfused with venom plus antivenom presented a mild deposit of proteinaceous material in the urinary space of the glomeruli as well as in the lumina of tubules. 


\section{DISCUSSION}

Accidents caused by Thalassophryne nattereri represent a medical problem in the northeast of Brazil (1-4). Animal experimentation proved that venom administration can produce nociception, edema, necrosis and lethality (5). Furthermore, venom injection into footpads of mice can provoke local inflammatory lesions, similar to those described in humans (5).

Thalassophryne nattereri venom also causes damage in skeletal muscle due to myotoxic effects and vascular alterations followed by impairing regenerative processes (6). We have recently shown that this venom is capable of modifying renal physiology, interfering especially on vascular parameters of isolated rat kidney. These alterations were probably due to myotoxic agents or to a direct effect of the venom on renal cells causing the release of vasoactive factors (8).

It was demonstrated through in vitro neutralization assays that antivenom administered to rabbits can completely neutralize the necrotic and nociceptive effects induced by $T$. nattereri venom, therefore justifying the use of serum therapy as an efficient treatment for this type of envenomation $(11,18)$.

As far as we know, the efficiency of $T$. nattereri antivenom in decreasing renal effects induced by $T$. nattereri venom had not been tested. In this study, we observed that $T$. nattereri venom previously incubated with antivenom is able to reduce PP, RVR, UF and GFR. An equal proportion of antivenom is necessary to cause a significant reduction of renal effects provoked by the venom. This is an important finding that shows the efficiency of the antivenom against venom effects on the kidney.

Histological results revealed that the antivenom was able to reduce proteinaceous deposits in the urinary space and renal tubule.

In conclusion, antibodies obtained by a persistent immune response in horses were able to diminish the effects of $T$. nattereri venom on isolated rat kidney. The results also support the possible use of antivenom therapy in treatment of envenomation produced by this fish. 


\section{REFERENCES}

1. Almeida VG, Rocha CM. Registro de acidentes com peixes peçonhentos e/ou venenosos. Rev Soc Bras Toxicol. 1989;2(1):49-51.

2. Lima LAF, Ferreira ML. Clinical and experimental studies regarding poisoning caused by a fish Thalassophryne nattereri (niquim). Ann Bras Dermatol. 2000;75(4):435-43.

3. Haddad Junior V, Pardal PPO, Cardoso JLC, Martins IA. The venomous toadfish Thalassophryne nattereri (niquim or miquim): report of 43 injuries provoked in fishermen of Salinópolis (Pará State) and Aracaju (Sergipe State). Brazil. Rev Inst Med Trop São Paulo. 2003;45(4):221-3.

4. Facó PE, Bezerra GP, Barbosa PSF, Martins AMC, Guimarães JÁ, Ferreira ML, Monteiro HSA. Epidemiology of the injuries caused by Thalassophryne nattereri (niquim) in Ceará State (1992-2002). Rev Soc Bras Med Trop. 2005;38(6):479-82.

5. Lopes-Ferreira M, Barbaro KC, Cardoso DF, Moura-da-Silva AM, Mota I. Thalassophryne nattereri fish venom: biological and biochemical characterization and serum neutralization of its toxic activities. Toxicon. 1998;36(2):405-10.

6. Lopes-Ferreira M, Núnez J, Rucavado A, Farsky SHP, Lomonte B, Ângulo Y, Moura-da-Silva AM, Gutierrez JM. Skeletal muscle necrosis and regeneration after injection of Thalassophryne nattereri (niquim) fish venom in mice. Int J Exp Pathol. 2001;82(1):55-64.

7. Lopes-Ferreira M, Moura-da-Silva AM, Piran-Soares AA, Ângulo Y, Lomonte B, Gutierrez JM, Farsky SHP. Hemostatic effects induced by Thalassophryne nattereri fish venom: a model of endothelium-mediated blood flow impairement. Toxicon. 2002;40(8):1141-7.

8. Facó PEG, Havt A, Barbosa PSF, Nobre ACL, Bezerra GP, Menezes DB, Fontele MC, Lopes-Ferreira M, Monteiro HSA. Effects of Thalassophryne nattereri fish venom in isolated perfused rat kidney. Toxicon. 2003;42(5):509-14.

9. Lima C, Clissa PB, Piran-Soares AA, Tanjoni I, Moura-da-Silva MM, LopesFerreira M. Characterization of local inflammatory response induced by Thalassophryne nattereri fish venom in a mouse model of tissue injury. Toxicon. 2003; 42(5):499-507.

10. Grund LZ, Souza VMO, Faquim-Mauro EL, Lima C, Lopes-Ferreira M. Experimental immunization with Thalassophryne nattereri fish venom: striking IL-5 production and impaired of $\mathrm{B} 220^{+}$cells. Toxicon. 2006;48(5):499-508. 
11. Lopes-Ferreira M, Moura-da-Silva AM, Mota I, Takehara HÁ. Neutralization of Thalassophryne nattereri (niquim) fish venom by experimental antivenom. Toxicon. 2000;38(8):1149-56.

12. Takehara HA, Soares AA, Fernandes I, Guidolin R, Távora JP, Higashi HG, Bruni FM. Development of a new antivenom: experimental evidence of the efficacy of horse serum against Thalassophryne nattereri fish venom. Mem Inst Butantan. 2003;60:956.

13. Bradford MM. A rapid and sensitive method for quantization of microgram quantities of protein utilizing the principle of protein-dye binding. Anal Biochem. 1976;72(1-2):248-54.

14. Bowman RH. Gluconeogenesis in the isolated perfused rat kidney. J Biol Chem. 1970;245(7):1604-2.

15. Fonteles M, Cohen JJ, Black AJ, Wertheim SJ. Support of renal kidney function by long-chain fatty acids derived from renal tissue. Am J Physiol. 1983;244(3):23546.

16. Walser M, Davidosn DG, Orloff J. The renal clearance of alkali-stable inulin. J Clin Invest. 1955;34(10):1520-3.

17. Martinez-Maldonato M, Opava-Stitzer S. Free water clearance curves during saline, mannitol, glucose and urea diuresis in the rat. J Physiol. 1978;280(2):487-97. 18. Piran-Soares AA, Komegae EN, Souza VMO, Fonseca LA, Lima C, LopesFerreira M. Neutralizing antibodies obtained in a persistent immune response are effective against deleterious effects induced by the Thalassophryne nattereri fish venom. Toxicon. 2007;49(7):920-30. 